NOTE

\title{
Kudoa alliaria in flesh of Argentinian hoki Macruronus magellanicus (Gadiformes; Merlucciidae)
}

\author{
Christopher M. Whipps ${ }^{1, *}$, Benjamin K. Diggles ${ }^{2}$ \\ ${ }^{1}$ Center for Fish Disease Research, Department of Microbiology, 220 Nash Hall, Oregon State University, Corvallis, \\ Oregon 97331-3404, USA \\ ${ }^{2}$ DigsFish Services Pty Ltd., 32 Bowsprit Cres, Banksia Beach, Queensland 4507, Australia
}

\begin{abstract}
Myxozoans of the genus Kudoa are widespread parasites of marine fishes and primarily infect the body musculature of their hosts. Although Kudoa species are not usually associated with host mortality, some do form macroscopic cysts in the tissue and some are associated with post mortem tissue degradation. This is of concern to commercial fisheries as fillets may be unmarketable due to these infections. Because different species of Kudoa have different effects on their hosts, it is important to correctly identify species with epidemiological relevance, distinguishing those that are benign from those that are associated with these detrimental effects. Using morphological and molecular analyses, we identified K. alliaria infecting Argentinian hoki Macruronus magellanicus. Comparisons of the small subunit ribosomal DNA sequence revealed that $K$. alliaria is genetically very similar to $K$. rosenbuschi. Furthermore, there is significant overlap in myxospore dimensions between descriptions of these 2 Kudoa species as well as those of other Patagonian fishes. Thus, without careful examination of the myxospore dimensions, it may be difficult to identify these species on a routine basis. It is critical to accurately identify $K$. alliaria as, unlike $K$. rosenbuschi, it is not associated with tissue degradation. Ambiguities in some species descriptions highlight the need for thorough morphological analyses accompanied by molecular comparisons to clarify the species boundaries between Kudoa parasites of Patagonian fishes.
\end{abstract}

KEY WORDS: Kudoa alliaria $\cdot$ Kudoa rosenbuschi $\cdot$ Myxospore morphology · Patagonia · Argentina · Small subunit ribosomal DNA

\section{INTRODUCTION}

Myxozoan parasites of the genus Kudoa (Multivalvulida: Kudoidae) primarily infect the muscle tissue of their fish hosts (Moran et al. 1999, Swearer \& Robertson 1999). Although Kudoa species may not be associated with host mortality, the manifestation of these infections by some species (macroscopic cysts, postmortem tissue degradation) is of concern to commercial fisheries as fillets may be unmarketable. In fishes of Patagonia (southern Chile and Argentina), 5 Kudoa species have been identified: $K$. alliaria, $K$. clupeidae, $K$. peruvianus, K. ramsayi, and $K$. rosenbuschi (see
Moran et al. 1999, Kalavati et al. 2000). Post mortem tissue degradation in the musculature of the fish host has been observed for $K$. rosenbuschi (see Sardella et al. 1987) and K. peruvianus (see Mateo 1972). Macroscopic cysts have been observed in the muscle of hosts infected with $K$. alliaria and $K$. ramsayi (Kovaleva et al. 1979, Kalavati et al. 2000). K. clupeidae has even been implicated in host mortality (Lom \& Dyková 1992).

With the exception of Kudoa ramsayi, which has stellate spores (Kalavati et al. 2000), the remaining species bear diminutive quadrate spores that are very similar to one another (Swearer \& Robinson 1999). Given that myxozoan spores, when compared to other metazoan 
phyla, possess relatively few features from which identifications and descriptions can be made, it has been suggested that molecular characterizations should accompany descriptions of new species (Kent et al. 2001). Recently, Abollo et al. (2005) sequenced the small subunit ribosomal DNA (SSU rDNA) gene of K. rosenbuschi. Based on a phylogentic analysis of this sequence, Abollo et al. (2005) found that K. rosenbuschi was closely related to the morphologically similar parasites K. clupeidae and K. funduli. In 2002, we received specimens of Argentinian hoki Macruronus magellanicus infected with a Kudoa species. It was our goal to identify this parasite by both morphological and molecular analyses.

\section{MATERIALS AND METHODS}

In August 2002, we received 3 specimens of frozen muscle tissue of Argentinian hoki Macruronus magellanicus containing cysts. The tissues had been frozen for up to $2 \mathrm{mo}$ at $-20^{\circ} \mathrm{C}$. After a brief cytological examination, the specimens were fixed in $95 \%$ ethanol and stored for 3 yr before the following more detailed microscopic and molecular investigations were undertaken.

For morphological analyses, digital images were taken of myxospores in wet mount preparations of ethanol-fixed muscle tissue using the SPOT version 3.5.5 for Windows camera and software (SPOT Diagnostic Instruments). Following the guidelines of Lom \& Arthur (1989), spore length, width and thickness, and polar capsule width and thickness were measured from multiple images with at least 10 measurements for each dimension.

Sequencing of the partial SSU rDNA employed existing polymerase chain reaction primers, parameters, and sequencing protocols as described previously (Whipps et al. 2003). This sequence was compared to those of other related Kudoa species as determined from previous analyses (Blaylock et al. 2004, Whipps et al. 2004, Abollo et al. 2005, Diamant et al. 2005) and using the basic local alignment search tool (BLAST) on GenBank (Altschul et al. 1990). Sequences were aligned with Clustal X (Thompson et al. 1997) and pairwise sequence similarities were generated with BioEdit version 7.0.5 (Hall 1999).

\section{RESULTS AND DISCUSSION}

Upon defrosting there was no evidence of myoliquefaction in the affected tissues. Specimen 1 consisted of 3 brown objects, likely cysts, 3 to $6 \times 1$ to $2 \mathrm{~mm}$ in dimension. Specimen 2 consisted of 4 or 5 sections of

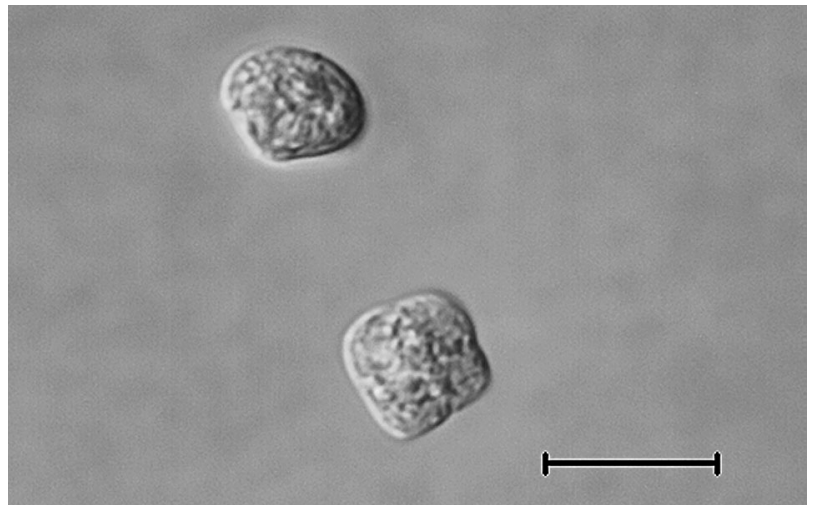

Fig. 1. Kudoa alliaria. Spores in lateral (top) and apical (bottom) aspect. Photographed following fixation in ethanol after being frozen at $-20^{\circ} \mathrm{C}$ for up to $2 \mathrm{mo}$. Scale bar $=10 \mu \mathrm{m}$

muscle tissue with numerous yellow to cream, round to oval-shaped cysts, 2 to $3 \mathrm{~mm}$ diameter, and 2 to $6 \mathrm{~mm}$ long, distributed amongst the muscle fibres. Specimen 3 consisted of 4 or 5 sections of muscle tissue with numerous white, oval-shaped cysts, 2 to $3 \mathrm{~mm}$ diameter, and 2 to $10 \mathrm{~mm}$ long, distributed amongst the muscle fibres. Although morphology of the cysts in each sample varied to some degree, myxozoan spores consistent with those of the genus Kudoa (4 polar capsules and valves) were observed upon microscopic examination of the cyst contents.

Spores were quadrate in apical view, rounded in lateral view, with visible valve sutures (Fig. 1). Mean (range) dimensions of spores from ethanol-fixed tissues were 6.35 (5.84 to 6.86) $\mu \mathrm{m}$ in length, 8.51 (7.84 to 9.25) $\mu \mathrm{m}$ wide, and 7.08 (6.46 to 7.55$) \mu \mathrm{m}$ thick (Table 1). Polar capsules were equal, pyriform, $2.60 \mu \mathrm{m}$ (2.27 to 2.82) long, and $1.61 \mu \mathrm{m}$ (1.40 to 1.87$)$ wide. Some spore features (i.e. sporoplasm, polar filaments) were difficult to discern, most likely due to fixation; ethanol fixation is known to cause some shrinkage of myxospores, reducing spore and polar capsule length by approximately $5 \%$, but spore width is less likely to be distorted (Parker \& Warner 1970). Thus, measurements made from ethanol-fixed material will be smaller, but very close to those made from fresh material.

Even with the assumption that there was some reduction in spore length due to alcohol fixation, the spores were morphologically most consistent with those of Kudoa alliaria (Table 1). Both the locality (Argentina) and host (Macruronus magellanicus) were consistent for this species and pseudocysts were white or yellow as described by Kovaleva et al. (1979). The pseudocysts from Specimen 1 were probably brown as a result of the accumulation of melanised breakdown products as the cysts were killed by the host immune response, as seen for other Kudoa species (Moran et al. 1999). 
Table 1. Kudoa spp. Comparison of myxospore dimensions for Kudoa species of Patagonian fishes. Mean measurements in $\mu \mathrm{m}$, range in parentheses

\begin{tabular}{|lllcccl|}
\hline Species & Host species & Locality & Length & Thickness & Width & Source \\
\hline K. alliaria & Macruronus magellanicus & Argentina & $6.35(5.84-6.86)$ & $7.08(6.46-7.55)$ & $8.51(7.84-9.25)$ & Present study \\
& Micromesistius australis & Argentina & $(7-8)$ & $(8-9)$ & $(9-10)$ & Kovaleva et al. (1979) \\
& Patagonotothen ramsay & Argentina & $(6.3-7.4)$ & $(6-6.3)$ & $(6.3-7.4)$ & Kovaleva et al. (1979) \\
K. clupeidae & Brevoortia tyrannus & Eastern USA & $5.25(5.0-5.5)$ & $6(5.5-6.5)$ & 6.5 & Reimschuessel et al. (2003) \\
& Brevoortia tyrannus & Eastern USA & 5.1 & 6.4 & - & Meglitsch (1947) \\
K. peruvianus & Merluccius gayi & Chile & $(4.65-5.10)$ & - & $(5.58-6.51)$ & Mateo (1972) \\
K. ramsayi & Patagonotothen ramsayi & Argentina & $(8.0-10.4)$ & $(2.8-4.8)$ & $(4.8-8.0)$ & Kalavati et al. (2000) \\
K. rosenbuschi & Merluccius hubbsi & Argentina & $(6-7)$ & 6.5 & 5.5 & Kovaleva et al. (1979) \\
& Merluccius gayii (sic) & Argentina & - & - & 7 & Gelormini (1944) \\
\hline
\end{tabular}

In the original description of Kudoa alliaria, Kovaleva et al. (1979) identified 4 different fish species as hosts: Micromesistius australis, Patagonotothen ramsay, Notothenia conina, and Macruronus magellanicus. Measurements were only provided for $K$. alliaria from 2 of these hosts (Table 1) and there are large differences in spore dimensions between the two. Kovaleva et al. (1979) suggested that these distinctions were probably connected with various conditions of existence in different hosts. Thus, some of the differences in dimensions observed here for $K$. alliaria from $M$. magellanicus could also be accounted for by variation between hosts. Similar morphological variation between hosts and locations has been shown for Kudoa iwatai (Diamant et al. 2005). However, as other studies indicate, it is equally likely that morphologically distinct spores from different hosts can represent separate Kudoa species (Whipps et al. 2003, Yokoyama et al. 2004).

Four other Kudoa species have been reported from fishes off the coasts of southern Argentina and Chile with morphological traits similar to those of $K$. alliaria (Table 1). K. peruvianus possesses smaller spores than $K$. alliaria and is found in waters off of Chile and Peru, but not Argentina. Because this species has significant overlap in dimension with $K$. rosenbuschi, K. clupeidae, (Table 1) and $K$. miniauriculata (see Whitaker et al. 1996), conspecificity of $K$. peruvianus with these species cannot be ruled out. $K$. ramsayi is likely a distinct species as its spores were described as stellate, not quadrate (Kalavati et al. 2000). Nonetheless, K. ramsayi and $K$. alliaria share the same host, Patagonotothen ramsay, and therefore further study is warranted.

Kudoa clupeidae is usually found in fishes of the western North Atlantic Ocean (Moran et al. 1999). However, there is a report of this species from Merluccius hubbsi in Argentina (Di Antonio \& Cenci Goga 1993). Unfortunately, in this report, measurements of spores are not provided and mention is not made of other parasites more commonly observed in this region (K. alliaria or $K$. rosenbuschi). Given that this is the type host and locality for $K$. rosenbuschi, which is morphologically similar to $K$. clupeidae, it is conceivable that Di Antonio \& Cenci Goga (1993) misidentified this parasite.

Such reports highlight the need for detailed descriptions for new species, and thorough identification of existing species when encountered. This is especially important for myxozoans, as spores possess a limited number of characteristics upon which identifications can be made. Furthermore, from reports published prior to the guidelines of Lom \& Arthur (1989) it is sometimes unclear as to exactly which spore dimension measurements are based upon. To overcome the limitations of morphology alone, it has been suggested that studies on myxozoan parasites incorporate DNA sequence analyses (Kent et al. 2001). Here, we sequenced most of the SSU rDNA of Kudoa alliaria. We obtained a $1680 \mathrm{bp}$ sequence and submitted this to GenBank (accession number DQ182561).

Based on pairwise comparisons, the SSU rDNA sequence of Kudoa alliaria was most similar to that of $K$. rosenbuschi (Table 2). In fact, these sequences only differed by 2 nucleotides across the entire sequence length. Other similar sequences were from $K$. funduli, a Kudoa sp., and K. clupeidae (all within $2 \%$ sequence

Table 2. Identity of Kudoa alliaria small subunit ribosomal DNA (SSU rDNA) (GenBank accession number DQ182561) to other Kudoa spp. SSU rDNA sequences available on GenBank. Sequence ambiguities were removed prior to calculation

\begin{tabular}{|lrr|}
\hline Species & $\begin{array}{c}\text { DNA sequence } \\
\text { identity to K. alliaria }\end{array}$ & $\begin{array}{c}\text { GenBank } \\
\text { acc. no. }\end{array}$ \\
\hline K. rosenbuschi & $1677 / 1679(99.9 \%)$ & AY623795 \\
K. funduli & $704 / 713(98.7 \%)$ & AY312279 \\
Kudoa sp. & $1542 / 1564(98.6 \%)$ & AY302723 \\
K. clupeidae & $1291 / 1311(98.5 \%)$ & AY197771 \\
K. miniauriculata & $1525 / 1564(97.5 \%)$ & AF034639 \\
K. dianae & $1514 / 1564(96.8 \%)$ & AF414692 \\
K. paniformis & $1505 / 1564(96.2 \%)$ & AF034640 \\
\hline
\end{tabular}


difference; Table 2). Molnár et al. (2002) also reported high sequence similarities between Myxobolus species, with $<1 \%$ sequence difference between SSU rDNA sequences from the morphologically similar Myxobolus pseudodispar, M. cyprini, and M. musculi. Likewise, K. minithyrsites and $K$. thyrsites exhibit only a $1.5 \%$ SSU sequence difference from one another (Whipps et al. 2003), and M. pendula differs from M. pellicides by only 8 bases across approximately $2000 \mathrm{bp}$ of SSU rDNA sequence (Kent et al. 2001).

Conversely, intraspecific SSU sequence differences have also been observed in geographically distant (allopatric) representatives of both Kudoa amamiensis and $K$. thyrsites, which have slightly different SSU rDNA sequences (Whipps et al. 2003). Intraspecific SSU sequence variation has even been observed for myxozoans from different host species living in sympatry, such as Myxidium lieberkuehni (see Schlegel et al. 1996) and M. pseudodispar (see Molnár et al. 2002). Thus, the high sequence similarity of $K$. alliaria to $K$. rosenbuschi does not necessarily equate to conspecificity, nor do the minor sequence differences mean they are separate species.

The distinction between Kudoa rosenbuschi and $K$. alliaria is somewhat unclear, especially given the variability between spore dimensions for $K$. alliaria observed here and those of Kovaleva et al. (1979) (Table 1). Both species possess quadrate spores, but $K$. rosenbuschi is reported to have more of a quadrangular platform at the apex of the spore, whereas the apex of $K$. alliaria spores is rounded off (Kovaleva et al. 1979). Thus, the species we observed here had spores most consistent with those of $K$. alliaria (Fig. 1). It is conceivable that such a minor morphological feature could be overlooked, perhaps more so if spores are not viewed laterally. Spores of $K$. alliaria are reported to be wider than those of $K$. rosenbuschi (Table 1). However, the resemblance of $K$. alliaria spores (Fig. 1) to those of K. rosenbuschi provided in figures by Sardella (1988) and Abollo et al. (2005) is striking. This is not to say that these authors made a misidentification, but simply illustrates some of the morphological similarities between these parasites.

There are currently no universal criteria, whether they are morphological or molecular, for determining boundaries between myxozoan species. However, consistent differences in these parameters observed in multiple specimens lend strong support to species distinctions. Genetic differences in a few specimens from a conserved gene such as the SSU rDNA are suggestive of an ecological separation, but not necessarily speciation (i.e. different sequences may represent multiple alleles of the same gene). It is important to identify genetically distinct parasite populations and species, especially where parasites are used for identi- fication of fish stocks (Sardella \& Timi 2004). Severity of infection, susceptibility of hosts, and distribution may vary between species. Among the Kudoa species discussed here, K. peruvianus and K. rosenbuschi are known to cause post mortem myoliquefaction of host tissues, whereas K. alliaria is not (Moran et al. 1999). K. clupeidae may even be associated with host mortality (Lom \& Dyková 1992). Modes of transmission may vary between species as both direct (Diamant 1997) and indirect (Koie et al. 2004) life cycles have been reported for marine myxozoans. Thus, although these species have very similar SSU rDNA sequences and are morphologically similar, their epidemiological relevance to fisheries differs.

It is critical that future studies and species descriptions employ careful morphological analysis of spores for identification of species. Molecular data should be included wherever possible, and may be needed from multiple genes, and/or ethanol-fixed samples should be deposited to a public database for use in future research. Only with thorough analysis of both morphological and molecular characteristics can the ambiguities between the Kudoa species of Patagonian fishes be clarified.

\section{LITERATURE CITED}

Abollo E, Novoa B, Figueras A (2005) SSU rDNA analysis of Kudoa rosenbuschi (Myxosporea) from the Argentinean hake Merluccius hubbsi. Dis Aquat Org 64:135-139

Altschul SF, Gish W, Miller W, Myers EW, Lipman DJ (1990) Basic local alignment search tool. J Mol Biol 215:403-410

Blaylock RB, Bullard SA, Whipps CM (2004) Kudoa hypoepicardialis n. sp. (Myxozoa: Kudoidae) and associated lesions from the heart of seven perciform fishes in the northern Gulf of Mexico. J Parasitol 90:584-593

Diamant A (1997) Fish to fish transmission of a marine myxosporean. Dis Aquat Org 30:99-105

Diamant A, Ucko M, Paperna I, Colorni A, Lipshitz A (2005) Kudoa iwatai (Myxosporea: Multivalvulida) in wild and cultured fish in the Red Sea: redescription and molecular phylogeny. J Parasitol 91:1175-1189

Di Antonio E, Cenci Goga BT (1993) Reperti parassitari riferibili a cisti di Kudoa clupeidae nel tessuto muscolare di merluzzi (Merluccius hubssj) congelati. Boll Soc Ital Patol Ittica 11:44-52

Gelormini N (1944) Un nuevo parásito de la merluza. Rev Fac Agron Vet Univ Buenos Aires 10:458-463

Hall TA (1999) BioEdit: a user-friendly biological sequence alignment editor and analysis program for Windows 95/98/NT. Nucleic Acids Symp Ser 41:95-98

Kalavati C, Brickle P, MacKenzie K (2000) Two new myxozoan parasites (Myxosporea, Multivalvulida, Bivalvulida) from fishes of the Falkland Islands. Acta Parasitol 45: $285-288$

Kent ML, Andree KB, Bartholomew JL, El-Matbouli M and 12 others (2001) Recent advances in our understanding of the Myxozoa. J Eukaryot Microbiol 48:395-413

Koie M, Whipps CM, Kent ML (2004) Ellipsomyxa gobii (Myxozoa: Ceratomyxidae) in the common goby Pomatoschistus microps (Teleostei: Gobiidae) uses Nereis spp. (Annel- 
ida: Polychaeta) as invertebrate hosts. Folia Parasitol 51: 14-18

Kovaleva AA, Shulman SS, Yakovlev VN (1979) Myxosporidia of the genus Kudoa (Myxosporidia, Multivalvulida) from the basin of the Atlantic Ocean. In: Systematics and ecology of sporozoans and cnidosporidians. Tr Zool Inst Akad Nauk SSSR 87:42-64 (in Russian).

Lom J, Arthur JR (1989) A guideline for the preparation of species descriptions in Myxosporea. J Fish Dis 12:151-156

Lom J, Dyková I (1992) Protozoan parasites of fishes. Elsevier, New York

Mateo E (1972) Investigacion parasitológica de la merluza (Merluccius gayii peruanus). Convenio entre el Instituto del mar y la Universidad Nacional Federico Villarreal, Inst. Mar Peru 40:3-13

Meglitsch PA (1947) Studies on Myxosporidia from the Beaufort Region. II. Observations on Kudoa clupeidae (Hahn), gen. nov. J Parasitol 33:271-277

Molnár K, Eszterbauer E, Székely C, Dán Á, Harrach B (2002) Morphological and molecular biological studies on intramuscular Myxobolus spp. of cyprinid fish. J Fish Dis 25: 643-652

Moran JDW, Whitaker DJ, Kent ML (1999) A review of the myxosporean genus Kudoa Meglitsch, 1947, and its impact on the international aquaculture industry and commercial fisheries. Aquaculture 172:163-196

Parker JD, Warner MC (1970) Effects of fixation, dehydration and staining on dimensions of myxosporidian and microsporidian spores. J Wildl Dis 6:448-456

Reimschuessel R, Gieseker CM, Driscoll C, Baya A and 6 others (2003) Myxosporean plasmodial infection associated with ulcerative lesions in young-of-the-year Atlantic menhaden in a tributary of the Chesapeake Bay, and possible links to Kudoa clupeidae. Dis Aquat Org 53:143-166

Sardella NH (1988) Descripción de la espora y de los estadios previos del mixosporidio Kudoa rosenbuschi, parásito muscular de Merluccius hubbsi. Ciclo de vida. Parasitol Día: Rev Soc Chilena Parasitol 12:8-13

Sardella NH, Timi JT (2004) Parasites of Argentine hake in

Editorial responsibility: Wolfgang Körting,

Hannover, Germany the Argentine Sea: population and infracommunity structure as evidence for host stock discrimination. J Fish Biol 65:1472-1488

Sardella NH, Trichinero JL, Manca EA (1987) Efectos del deterioro producido por mixosporidios de la especie Kudoa rosenbuschi en la musculature de Merluccius hubbsi. Informe Téch-Inst Nac Invest Desarrollo Pesq 7:105-112

Schlegel M, Lom J, Stechmann A, Bernhard D, Leipe D, Dyková I, Sogin ML (1996) Phylogenetic analysis of complete small subunit ribosomal RNA coding region of $M y x-$ idium lieberkuehni: evidence that Myxozoa are Metazoa and related to the Bilateria. Arch Protistenkd 147:1-9

Swearer SE, Robertson DR (1999) Life history, pathology, and description of Kudoa ovivora n. sp. (Myxozoa, Myxosporea): an ovarian parasite of Caribbean labroid fishes. J Parasitol 85:337-353

Thompson, JD, Gibson TJ, Plewniak F, Jeanmougin F, Higgins DG (1997) The ClustalX windows interface: flexible strategies for multiple sequence alignment aided by quality analysis tools. Nucleic Acids Res 24:4876-4882

Whipps CM, Adlard RD, Bryant MS, Lester RJG, Findlay V, Kent ML (2003) First report of three Kudoa species from eastern Australia: Kudoa thyrsites from Mahi mahi (Coryphaena hippurus), Kudoa amamiensis and Kudoa minithyrsites n. sp. from Sweeper (Pempheris ypsilychnus). J Eukaryot Microbiol 50:215-219

Whipps CM, Grossel G, Adlard RD, Yokoyama H, Bryant MS, Munday BL, Kent ML (2004) Phylogeny of the Multivalvulidae (Myxozoa: Myxosporea) based upon comparative rDNA sequence analysis. J Parasitol 90:618-622

Whitaker DJ, Kent ML, Sakanari JA (1996) Kudoa miniauriculata n. sp. (Myxozoa, Myxosporea) from the musculature of bocaccio (Sebastes paucispinus) from California. J Parasitol 82:312-315

Yokoyama H, Whipps CM, Kent ML, Mizuno K, Kawakami H (2004) Post-mortem myoliquefaction caused by Kudoa thyrsites (Myxozoa: Multivalvulida) from Japanese flounder and Kudoa lateolabracis n. sp. from Chinese sea bass. Fish Pathol (Gyobyo Kenkyu) 39:79-85

Submitted: September 6, 2005; Accepted: November 7, 2005 Proofs received from author(s): March 3, 2006 